Relations industrielles

Industrial Relations

\title{
Contemporary Labor Issues, Foget and Kleingartner, Wadsworth Publishing, Belmont, 1966, 462 pages.
}

\section{Pierre Dionne}

Volume 22, numéro 3, 1967

URI : https://id.erudit.org/iderudit/027820ar

DOI : https://doi.org/10.7202/027820ar

Aller au sommaire du numéro

Éditeur(s)

Département des relations industrielles de l'Université Laval

ISSN

0034-379X (imprimé)

1703-8138 (numérique)

Découvrir la revue

Citer ce compte rendu

Dionne, P. (1967). Compte rendu de [Contemporary Labor Issues, Foget and Kleingartner, Wadsworth Publishing, Belmont, 1966, 462 pages.] Relations industrielles / Industrial Relations, 22(3), 451-452.

https://doi.org/10.7202/027820ar

Tous droits réservés @ C Département des relations industrielles de l'Université Laval, 1967
Ce document est protégé par la loi sur le droit d'auteur. L'utilisation des services d'Érudit (y compris la reproduction) est assujettie à sa politique d'utilisation que vous pouvez consulter en ligne.

https://apropos.erudit.org/fr/usagers/politique-dutilisation/ 
of Eccnomics). The report of the Australian low entitled \& Restraints of Trade Union Activity in Australia $\$$, was prepared by H.J. Glasbeek, a member of the Bar of Victoria (Australia), formely Senior Tutorin-law at the University of Melbourne, and now Assistant Professor of Law at the University of Western Ontario. The report on the United States law, entitled \& The Labor Injunctions in the United States $\gg$, was prepared by Benjamin Aaron, Professor of Low and Director of the Institute of Industriol Relations in the University of Colifornia ot Los Angeles.

\section{Pierre DIONNE}

The Settlement of Labor Disputes on Rights in Australia, Paul F. Brisseden, Monograph series: 13, Institute of Industrial Relations, University of Californio, Los Angeles, 1966,125 pages.

In these pages are the results of an cttempt to explain to American readers how the Australian systems of industrial orbitration are utilized to deal with industrial grievances, or labor disputes over rights. Since the Australian arbitral apparatus was built up as machinery for the settlement primarily, of disputes over interests, and wos utilized only later, and somewhat as on ofterthought, for dealing with rights, it has seemed necessary to give some attention to the systems as a whole, and even to consider their utilization in disputes over interests. Not only is reliance in Australio in large measure upon the same apparatus for handling the two classes of disputes, but also the processes followed are often identical or closely similar.

So, the author discuss the settlement of interest disputes only insofar as necessary to get some perspective on the moving parts in the Australion arbitral system and to see how they are brought to bear on rights disputes

The inquiry into the Australian system is introduced by a summary description of the continent and the Commonwealth which occupies it. The author then compare the arbitral process in Australia and the analogous process in the United States and note the peripheral nature of the role of collective bargaining in Australia. There frilows a brief discussion of the origins and general features of the federal and state arbitral systems and the «two-story wage structure Down Under.
The second chapter presents a description of the Australian arbitral apparatus in the federal jurisdiction and in the four state jurisdictions in which such machinery operates, with emphasis upon the state system in New South Wales.

The next two chapters seek to explore the doctrines of interstateness and of ambit and the limitations these place upon the freedom of action of the tribunals in dealing with the wage structure and upon a careful distinction between lobor disputes on rights and those on interest.

Discussion of the operation of the arbitral apparatus occupied the largest section of the monograph. Here the analysis centers upon the principal channels and devices through which disputes on rights are dealt with, such as boards of reference, industrial mogistrates, industrial courts, major tribunols, award making, award variation, collective bargaining, and industrial action Seventeen cases, illustrating most of the methods and involving most of the classes of tribunals, are outlined in the hope that in this way some color of reality may be given to an exposition which otherwise might well seem somewhat fourth-dimensional.

The final chapters, again, point up some differences and similarities between the Australian and the American systems and cffer some concluding observations.

\section{Pierre DIONNE}

Contemporary Labor Issues, Foget and Kleingartner, Wadsworth Publishing, Belmont, 1966, 462 pages.

This book represents an attempt to provide a more exciting approach to the study of labor. The experience of the author in teaching courses in labor and industrial relations has convinces him that a high degree of student interest in these courses can be awokened by exposing the students to important current issues in the field of labor-issues which have contemporary meaning to people who are interested in what is going on in the world in which they live. Too often, a seminal intrigue with labor problems is stifled by an excessively intellectual or uninspiring presentation of traditional academic subjects. The author believe that an issues approach will stimulate interest in labor problems which will be accompanied and followed by effective learning of appropriate subject matters. 
This book is meant to awaken motivotion obout a variety of labor problems, by its use as a supplement to a textbook in college courses or as the basis for discussion in cdult programs where the participants already have some understanding of labor and industrial relations.

The problems of unemployment, minority welfare, leisure and automation are not more related to union activity than they are to the conduct of others institutionsemployees, schools, civic groups, and political parties, for example. These labor issues need to be presented in their own right-not just in their relation to the organized sector of the labor force. Three chapters, - unemployment, the disadvantaged, work and leisure - provide this kind of presentation. They are in Part one: "The Broad Contexty

Part Two: \&abor's Involvement include six chapters - Is there still a labor Movement? Must Union Membership Decline? Inside the Unions Innovations in Collective Bargaining, the Role of Government in Industriol Relations, Labor and Politics - which are oriented largely, though not completely, oround organized lobor.

Several chapters in each part are divided into sections so that the reader may easily grosp the major issues that are covered.

\section{Pierre DIONNE}

\section{Days of Our Years with Labor,par Robert C. Knee, The W.H. Anderson Company, Cincinnati, 1966, 160 pages.}

Essentiellement, ce livre est une histoire concise du développement du droit du trovoil en Amérique depuis ses débuts. Malgré I'impossibilité de trancher au couteau les trois grandes phases de croissance du droit du trovoil, à sovoir l'ère de la conspiration criminelle, l'ère des injonctions et l'ère interventionniste, l'auteur essaie quand même d'identifier chacune d'elles dans l'histoire des Etats-Unis. Pour refaire, il part de la période pré-révolution civile pour aboutir à la Loi sur les heures de travail de 1962, en passant évidemment par les fameuses lois Wogner, Thaft Hortley, Landum Griffin et Norris Lo Guordio.

Chose remarquable à noter quant à la méthode utilisée, l'auteur se fait un devoir de toujours expliquer le contexte historique qui o entouré l'adoption de chacune des lois influençont le syndicot et l'employeur.

\section{Jean SEXTON}

Labor Relations, by Arthur A. Sloane et Fred Witney, Prentice Hall Iric., Englewood Cliffs, N.J., 1967, 450 poges.

A unified treatment of the labor-manogement field, focusing on collective bargaining, with emphasis on the development and application of today's vital bargaining issues, together with ten orbitration cases to present a practical application of theories, this is Labor Relations.

By means of description, analysis, discussion questions and arbitration cases drawn from the author's own experiences, this book describes all basic phases of labor relations and how they offect the business man.

The direction which this book will take is an obvious one: downward from a brood overview of the general noture of the lobormanagement relationship as it currently exists in the United States (Port 1), through a survey of the historical, legal and structural environments which so greatly influence contractuol contents and labor relation, behovior (Part 2), to a close examination of the negotiation, administration, and major contents of the labor contract itself (Part 3)

Let us reconsider each part separately. In part one, the authors set the stage by explaining the stote of the unions todoy, the reasons for workers to join unions, for manager to resist them, and the management philosophies toword unions.

In part two Sloane and Witney describe the historical framework from the eighteenth century, to the AFL-CIO reality. The outhors also explain in this port both the legol framework, from the era of judiciol control to the Landum Griffin and the union structure, government and operation.

Finally, the main part of this book is dedicated to the collective bargaining; the preparation for negotiations, the bargaining process, the administration of the agreement, the wage issues, the economic supplements, the institutional and administrative issues of collective bargaining.

We could resume the content of this book by describing some of its highlights: 